\title{
Estimating willingness to pay for the Covid-19 vaccine using the conditional valuation method
}

\author{
Omid Ali Adeli ${ }^{1}$, Sanaz Rahimi kah kashi ${ }^{1 *}$ \\ 1. School of Economics and Management, University of Qom, Iran
}

Received: 6 January 2021

Accepted for publication: 13 April 2021

[EPub a head of print- 19 April 2021]

Payesh: 2021; 20 (2): 223-236

\begin{abstract}
Objective: Conditional valuation method is one of the methods of estimating the willingness to pay and is a cost-benefit analysis. The aim of the present study was to estimate the average willingness of individuals to pay for the Covid-19 vaccine with a one-year and long-term protection period and to assess its contributing factors.

Methods: The present study was a descriptive research. The required data were collected from 370 two-dimensional online questionnaires at the end of November 2020 from Iranians. Conditional valuation method and logit model were used to estimate peoples' willingness to pay.

Results: The results showed that 65.67 percent of people are willing to pay for the vaccine. The household income, age, history of having chronic disease, history of Covid-19, attitude, recommended amount and having an elderly person in the family had a positive and significant effect on long-term vaccination and age, household income, history of having chronic disease, attitude and the amount offered had a positive and significant effect on annual vaccination. Also, the average willingness to pay was 3,750,000 Rials per person for long-term vaccination, and 1,130,000 Rials per year.

Conclusion: In conditional valuation studies, individuals typically offer a lower bid for the policy under study. However, this study indicated that people are willing to pay more for vaccinations. The findings might have some implications for policy and planning.
\end{abstract}

Key Words: Covid - 19, Vaccine, Conditional valuation, willingness to pay, logit model

\footnotetext{
* Corresponding author: School of Economics and Management, University of Qom, Iran

E-mail: sanazrahimi137@gmail.com
} 


\title{
بر آورد تمايل به برداخت براى واكسن كوويد - 19 با استفاده از روش ارزش حكذارى مشروط
}

\author{
* اميد على عادلى ' ساناز رحيمى كاه كشى \\ 1. دانشكده اقتصاد و مديريت، دانشگاه قم، قم، ايران

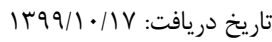

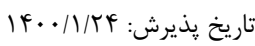

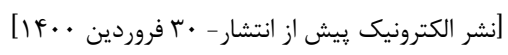

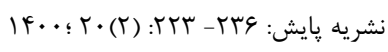

جكيده

مقدمه: وجود بحران اييدمى كوويد - 19 در جهان، ضرورت انجام مطالعات همه جانبه در اين زمينه را به وجود مى آورد. واكسيناسيون به عنوان

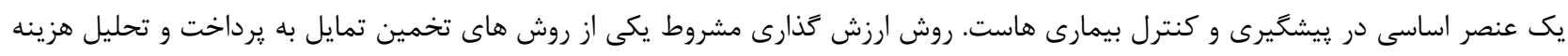

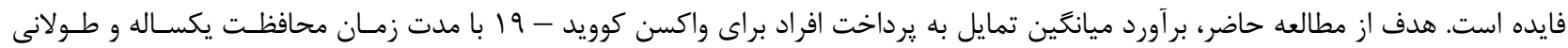

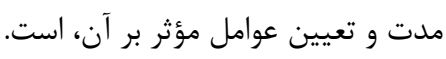

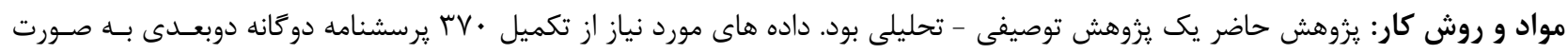

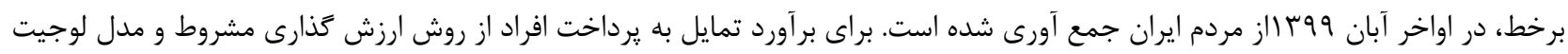
استفاده شده است.

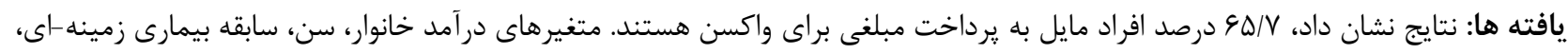

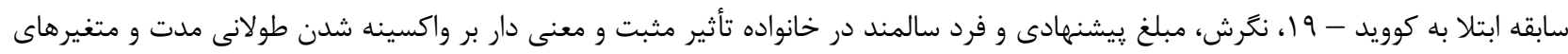

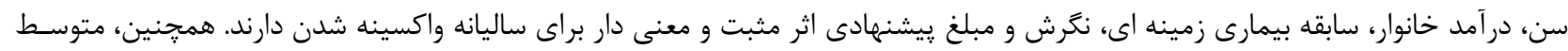

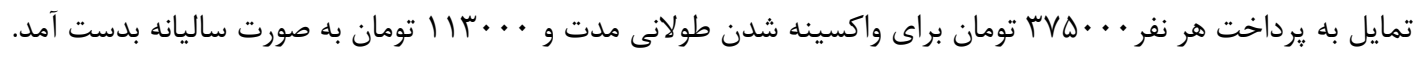

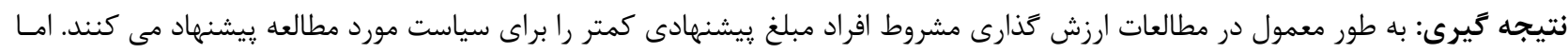

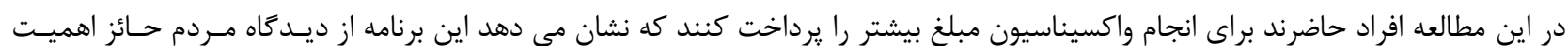

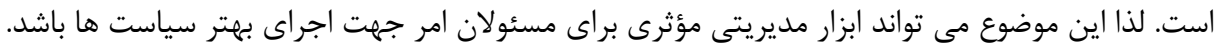

كليدوازه: كوويد - 19 ، واكسن، ارزش كذارى مشروط، تمايل به يرداخت، مدل لوجيت

* نويسنده باسخكو: قم، دانشكاه قم، دانشكده اقتصاد و مديريت ق

E-mail: sanazrahimi137@gmail.com 


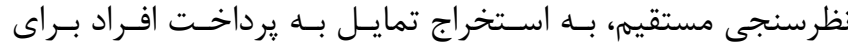

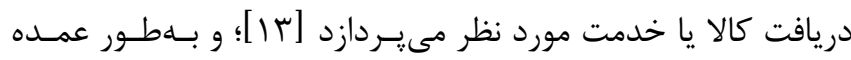

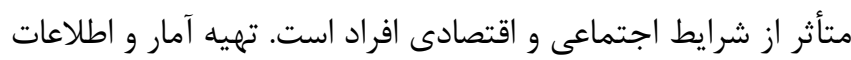

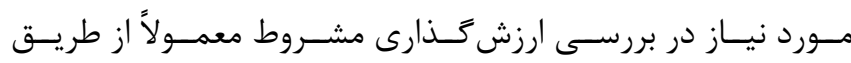

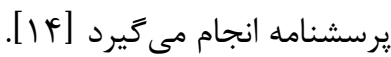

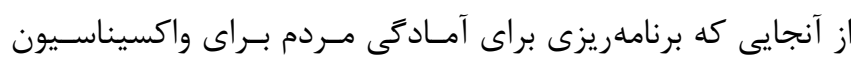

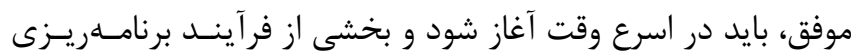

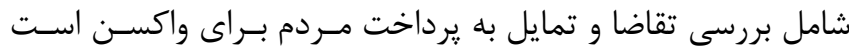

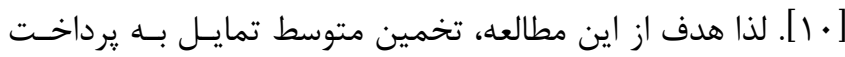

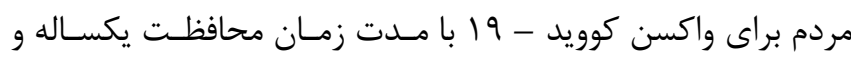

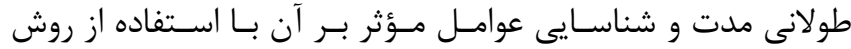

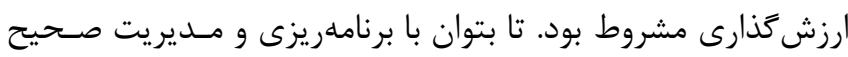

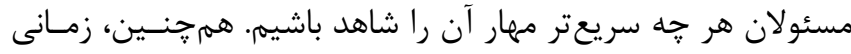

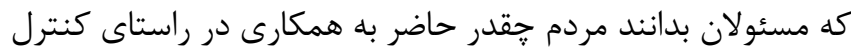
و سركوب اين بيمارى هستند، بهتر مى توانند در اين زمينه تصميم-

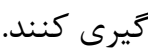

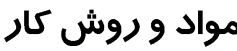

يزوهش حاضراز نوع مطالعات كاربردى و روش تحقيـق، توصـيفى - مارد

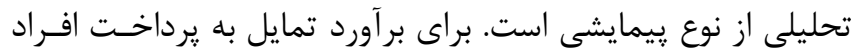

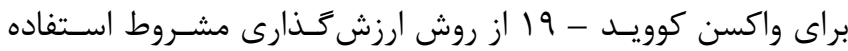

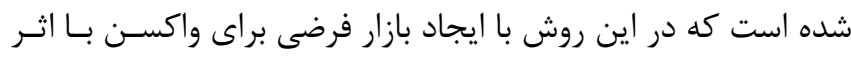
بخشى بالا، دو سطح مدت محافظت يكساله و طولانى مـدت مطـرح

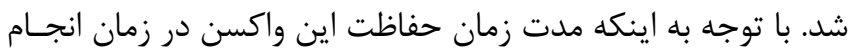

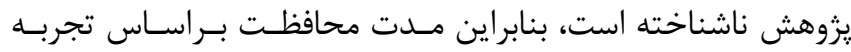

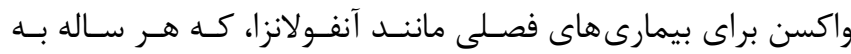
واكسن نياز دارد و سناريوى واكسنى با مدت زمان طولانى مدت، بـاسـا توجه به برخى تحقيقات كزارش شده كه ويروس كرونا بسيار آهسته

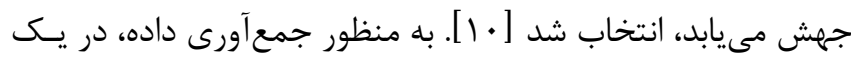

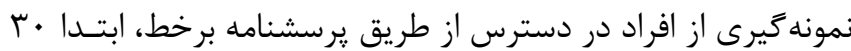

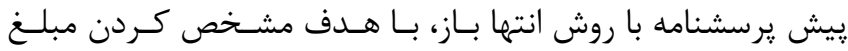

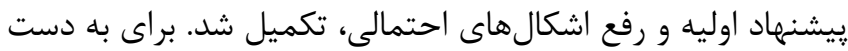

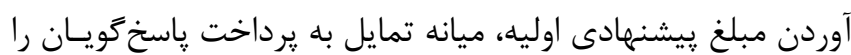

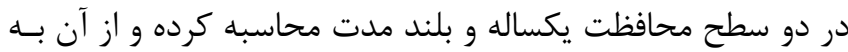

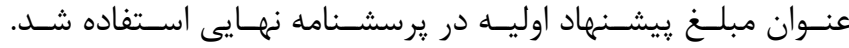

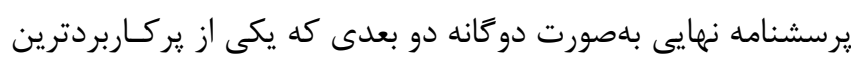

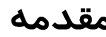

يِيدايش ويروس كوويد - 19 در جهان يديدهاى نوظهـور اسـت كـهـ

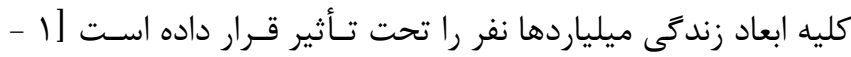

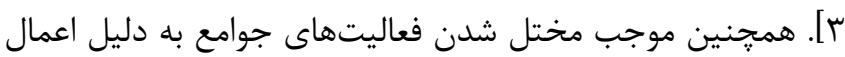

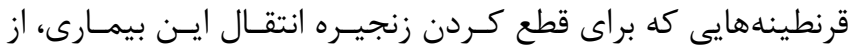

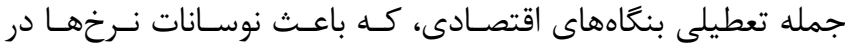

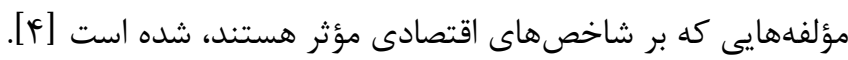

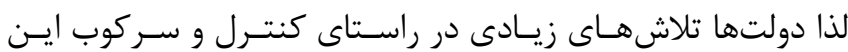

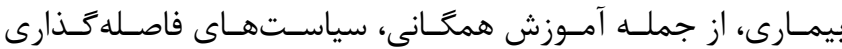

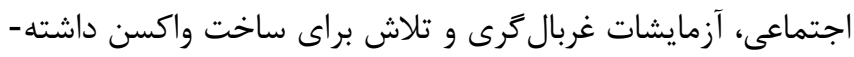

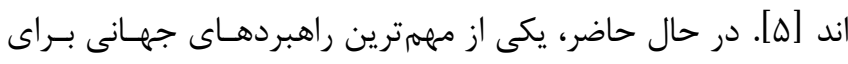

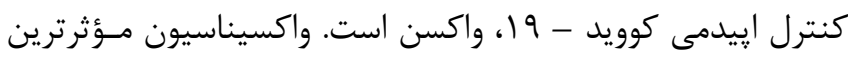
راه براى كنترل بيمارىهاى قابل سرايت عفونى به ويزه در كروههاى

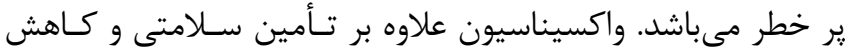

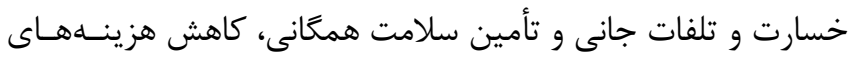

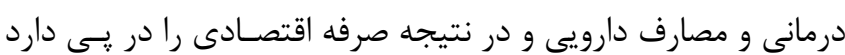

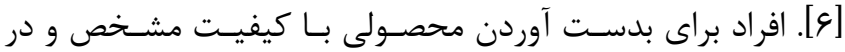
نتيجه افزايش مطلوبيت و رفاه خود حاضرند مبلغسى را بيردازنسد، در برد

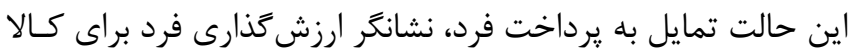

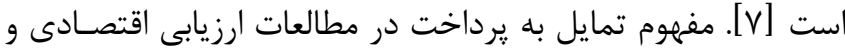

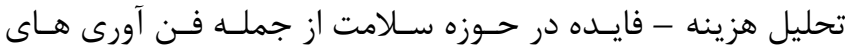

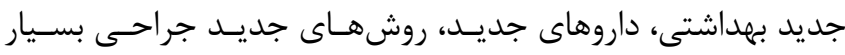

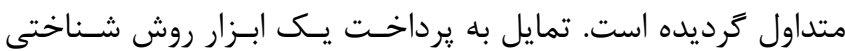

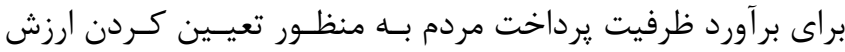

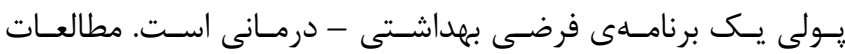

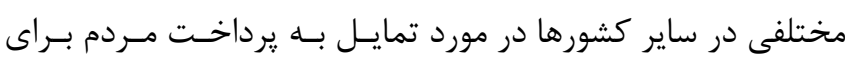
واكسيناسيون بيمارى هاى واكير انجام شـده اسـتـ از جملـهـ تـاثير

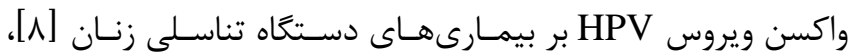

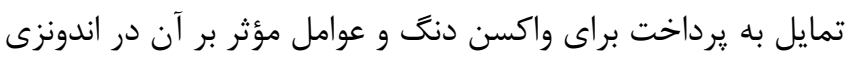

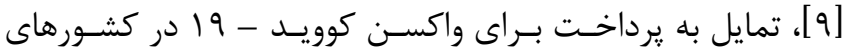

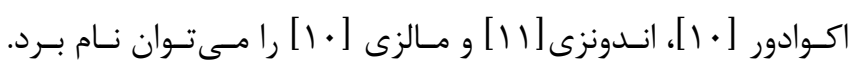
بسيارى از اين مطالعات از روش ارزش كذارى مشروط براى تخمـين

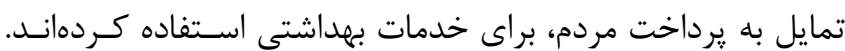

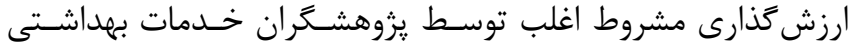

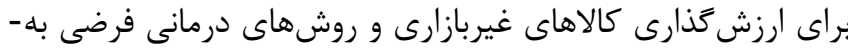

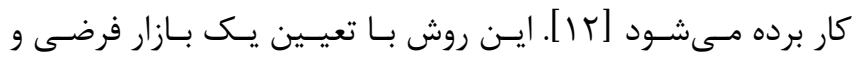


برسشنامه است. جامعه آمارى يزوهش مردم ايران است. تعداد نمونه

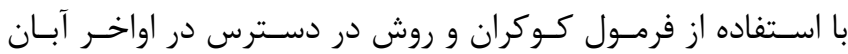

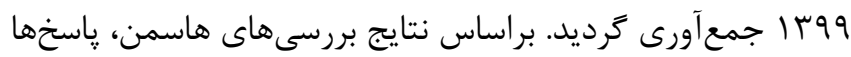

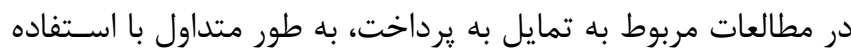

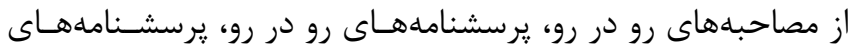

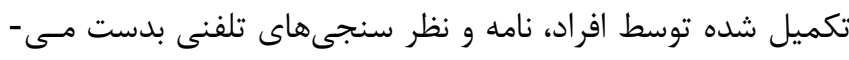

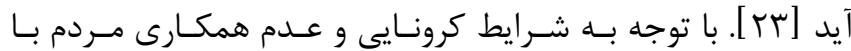

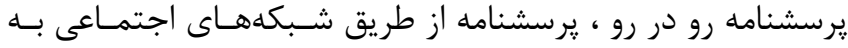

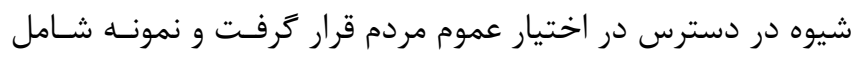

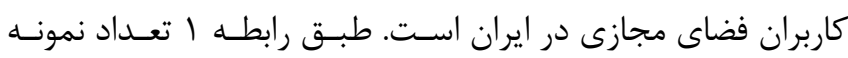

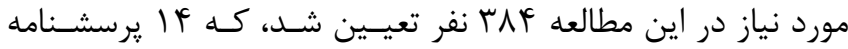

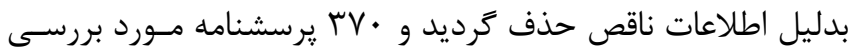

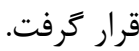
$n=\frac{N \cdot p \cdot q \cdot t^{2}}{N \cdot d^{2}+p \cdot q \cdot t^{2}}=\frac{79926270 * 0.5 * 0.5 * 1.96^{2}}{79926270 * 1.96^{2}+0.5 * 0.5 * 1.96^{2}}=384$

رابطه (1)

در اين رابطه؛ n تعداد افراد نمونسه، N تعـداد كـل جامعـهى آمـارى

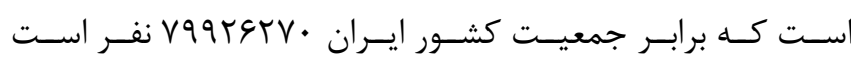

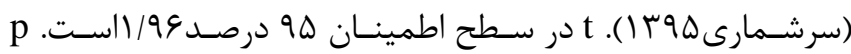
درصد احتمال تمايل به يرداخت، q درصد احتمال عـدم تمايـل بــهـ

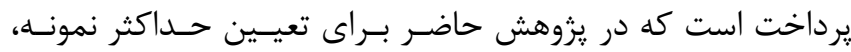

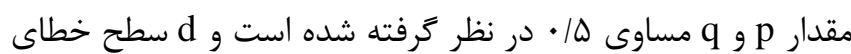

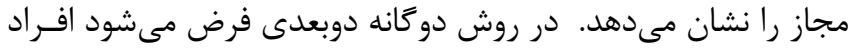
$U=U(Y, S)$

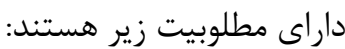
رابطـهـ (r)

در رابطه فوق U مطلوبيت غيرمستقيمى است كه فرد بهدست مسى-

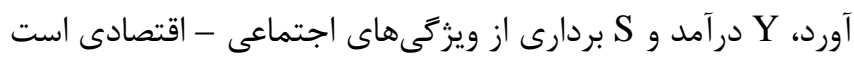

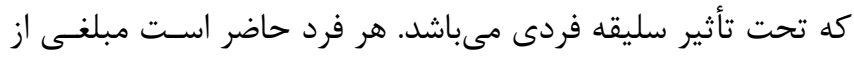

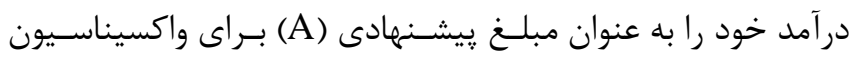

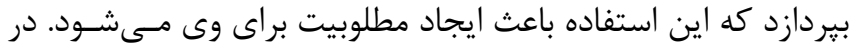
نتيحه:

$$
U(1, Y-A ; S)+\varepsilon_{1} \geq U(0, Y ; S)+\varepsilon_{0}
$$

) رابطه (广)

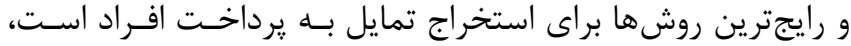

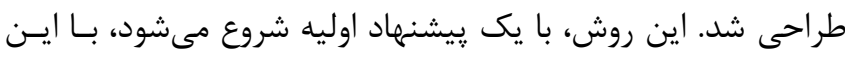

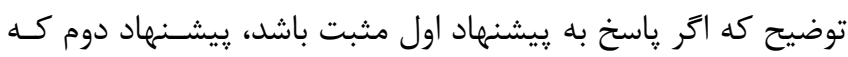

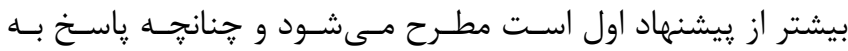

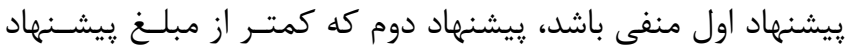

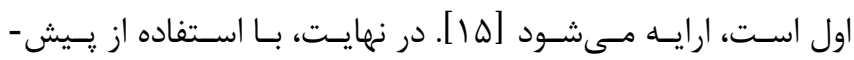

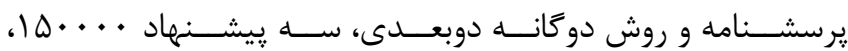

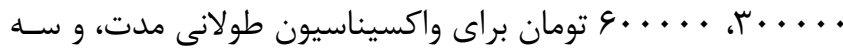

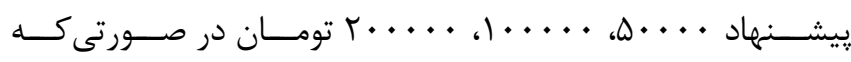
واكسيناسيون به صورت ساليانه انجام شود، بدست آمد.

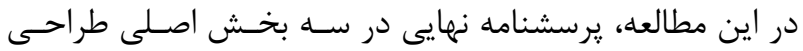

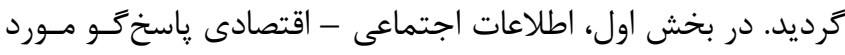

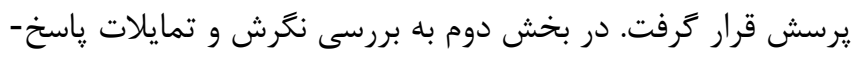

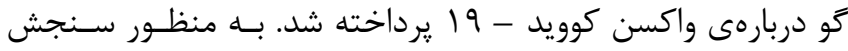

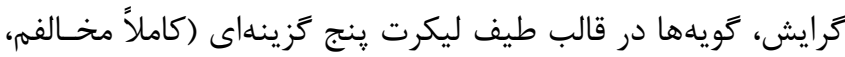

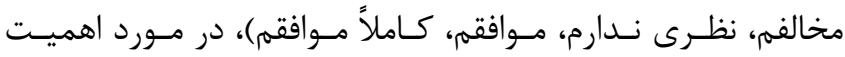
واكسينه شدن و هزينههاى اجتماعى - اقتصادى آن بـه فـرد ارايـهـ

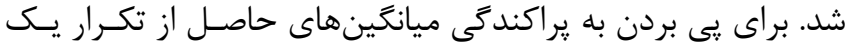

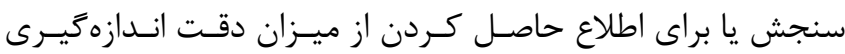

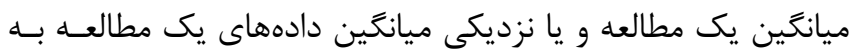
ميانكَين واقعى جمعيت هدف، از انحراف از ميانكين استفاده مى شود

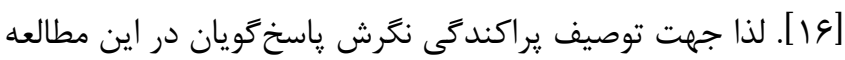

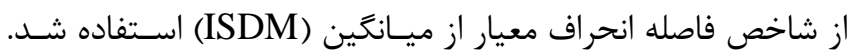
نحوه امتيازات كسب شده به جهار سطوح، بدين شرح برآورد كرديد:

$[1\}]$

A= نحرش منفى

Min $\leq$ A $<$ Mean-St.d

B= نكرش نسبتاً منفى

Mean-St.d $\leq \mathrm{B}<$

Mean

C $=$ نحرش نسبتاً مثبت $\quad$ Mean $\quad$ C

Mean+St.d

Dت نكرش مثبت

Mean+St.d $\leq$ D $<$ Max

در بخش نهايى، كه بخش اصلى يرسشنامه است با ايجـاد سـناريوى

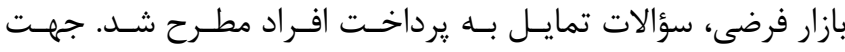

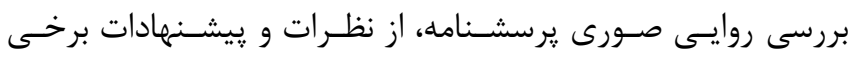

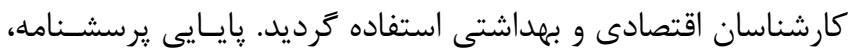

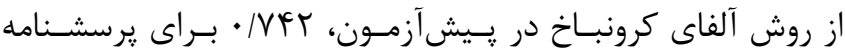

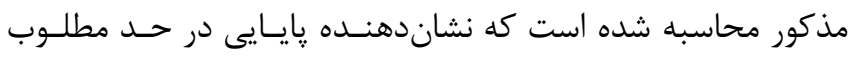




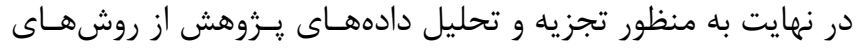

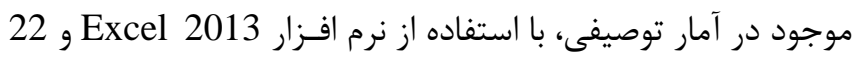

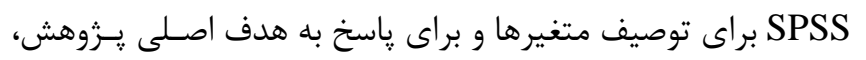

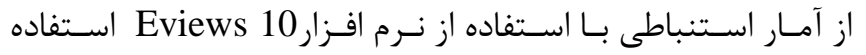

\section{يافتهها}

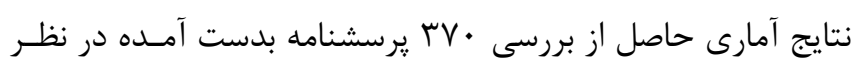

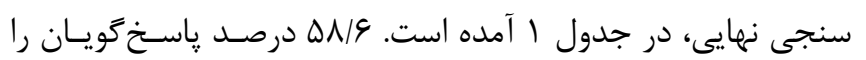

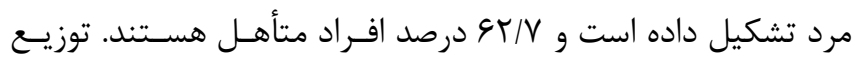

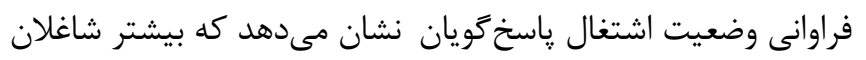

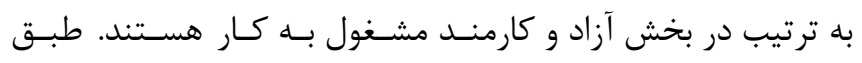

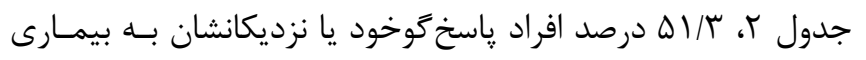

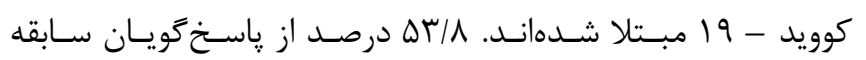

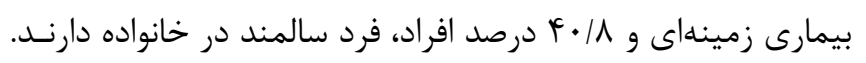

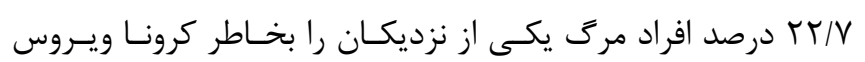

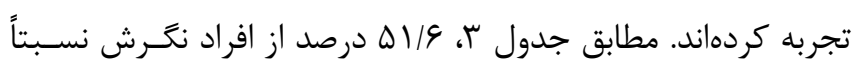

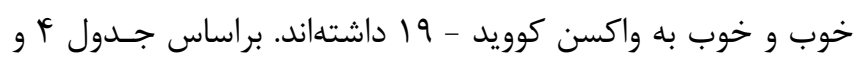

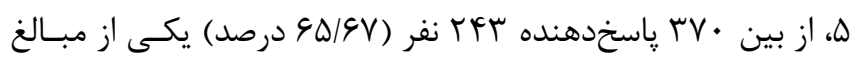

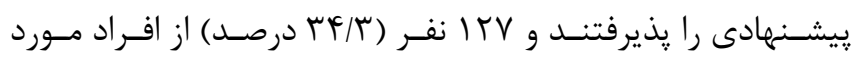

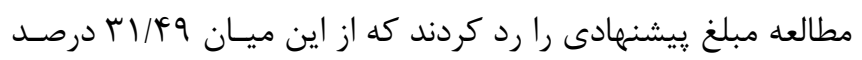

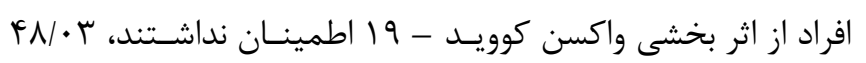

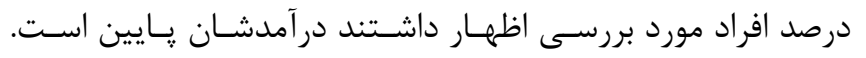

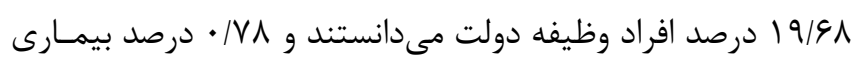
كوويد - 19 را خطرناك نمى دانستند.

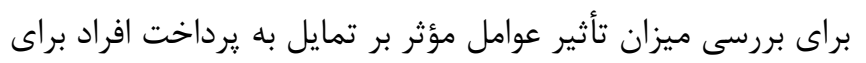

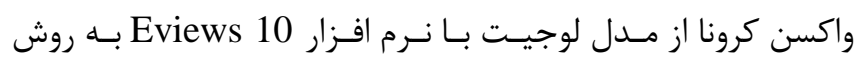

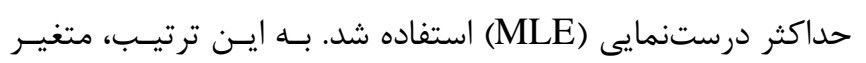

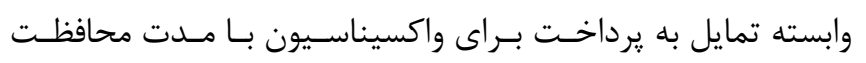

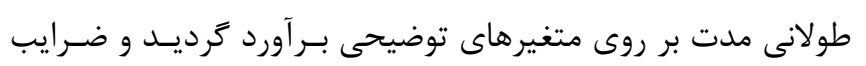

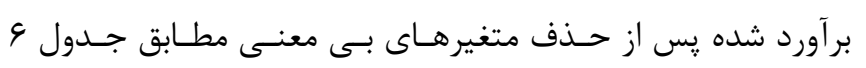
بدست آمدند. ضريب متغير مبلغ بيشنهادى به عنوان يكى از متغيرهاى توضـيحى داند

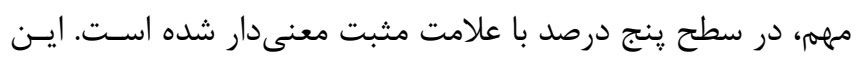

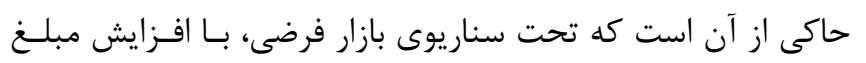

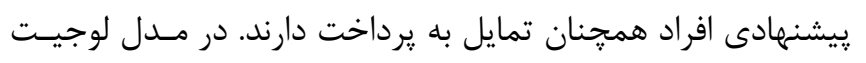

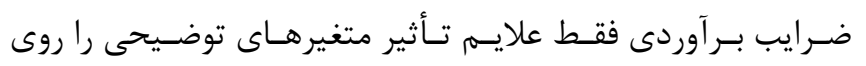

فرض مىشود ميزان مطلوبيت ايجاد شده در اثر اسـتفاده از واكسـن بيشتر از حالتى است كه فرد از واكسن استفاده نمسى كنــد.

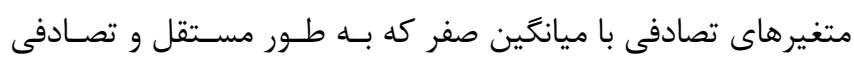
توزيع شدهاند، است.

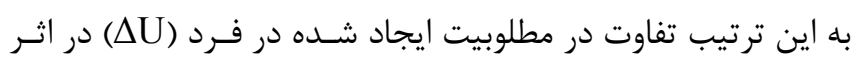

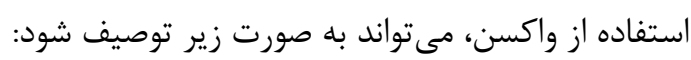
$\Delta \mathrm{U}=\mathrm{U}(1, \mathrm{Y}-\mathrm{A} ; \mathrm{S})-\mathrm{U}(0, \mathrm{Y} ; \mathrm{S})+\left(\varepsilon_{1}-\varepsilon_{0}\right)$

(i) رابطه

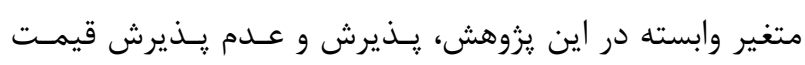

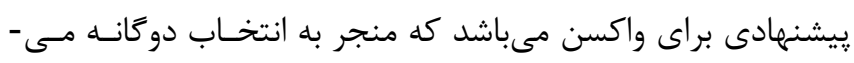

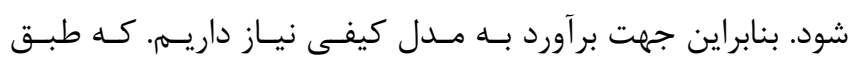

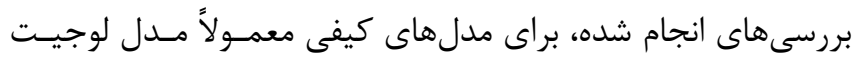

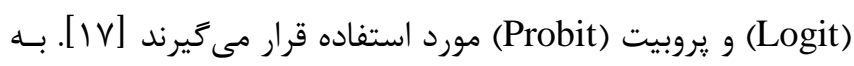

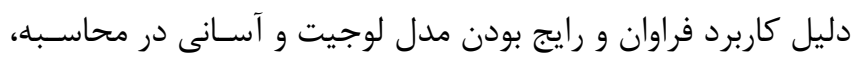
در اين تحقيق از اين مدل استفاده مى شود.

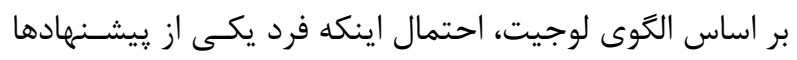

$$
\text { را بيذيرد به صورت رابطه f بيان مىشود: }
$$

$p_{i}=f_{y}(\Delta u)=\frac{1}{1+\operatorname{axp}(-\Delta u)}=\frac{1}{1+\operatorname{axp}(-(\alpha-\beta A+\gamma \gamma+\theta s))}$ (Q) رابطه (1)

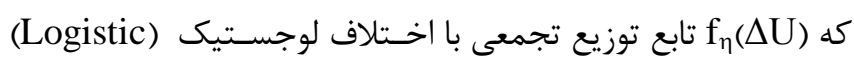

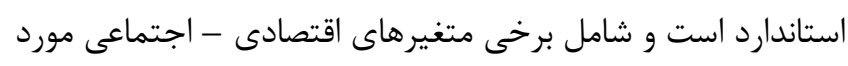

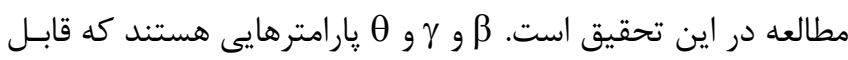

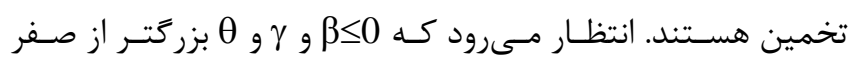
باشند [11]

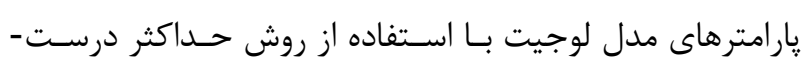

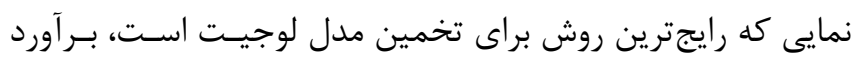

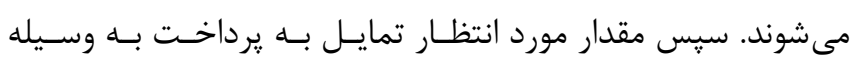

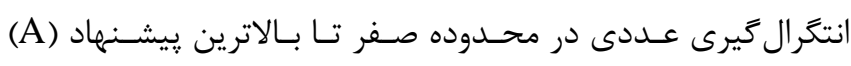

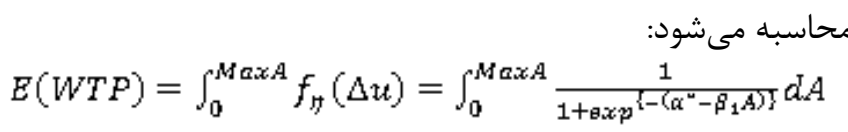
(9) رابطه

$\alpha^{*}=(\alpha+\gamma Y+\theta S)$ (V) رابطه

مقدار مورد انتظار تمايل به برداخت و E (WTP)

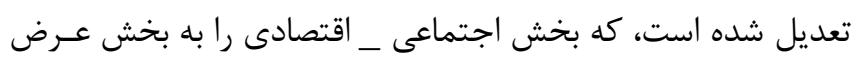

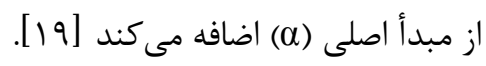


به يرداخت مىشود. ضـريب متغيـر داشـتن سـالمند در خـانواده در

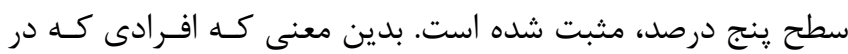

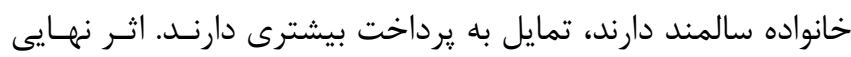
اين متغير بيانكر اين است كه افزايش يك واحدى در متغير سالمند در خانواده، در صورت ثابت بودن ساير عوامل، منجر به افـزايش 11 درصدى در احتمال تمايل به يرداخت مىشود.

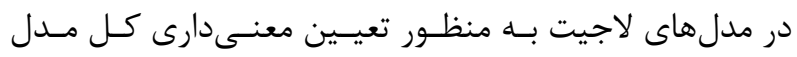

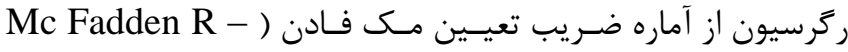
كه از معيارهاى خوبى برازش است، اسـتفاده مسىشـود. (Squared

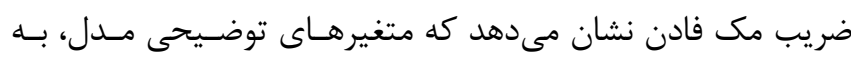

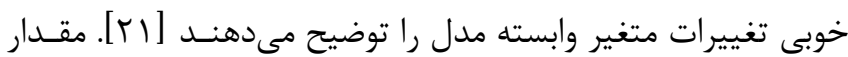

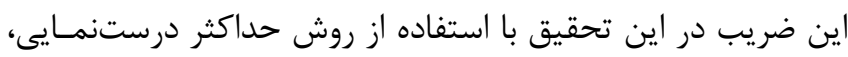

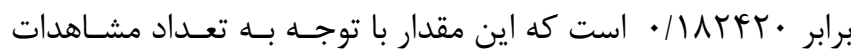
متغير وابسته، مقدار مطلوبى اسـت. بــراى بررسـى معنـى دارى كـل

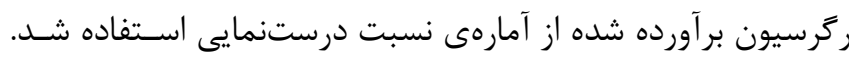

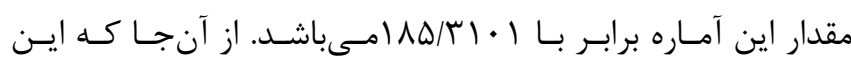

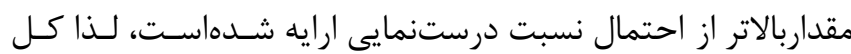

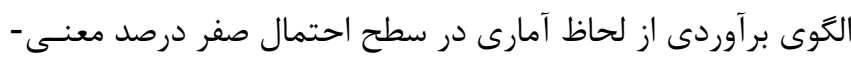

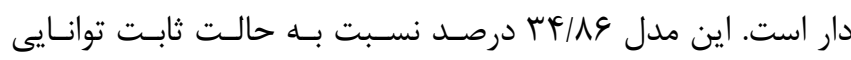
تخمين بهترى را داشته است. بنابراين الخـوى فـوق قابـل اطمينـان براى تجزيه و تحليلهاى بعدى است.

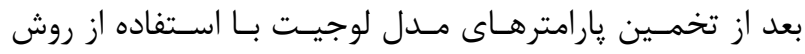
حداكثر درستنمايى، به وسيله انتخــرال خيـرى عـددى در محسـدوده

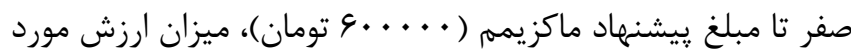
انتظار به صورت رابطه V محاسبه شد.

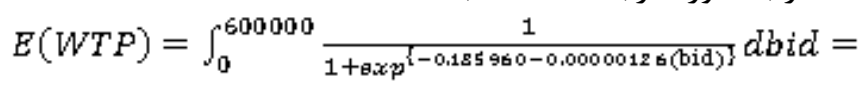

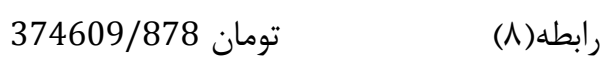

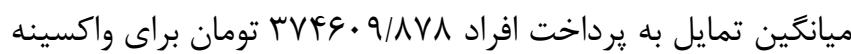
شدن طولانى مدت برآورد شد. با توجه به اينكه ميانگين بعد خـانوار

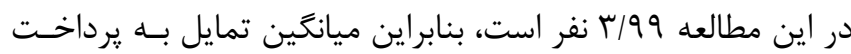

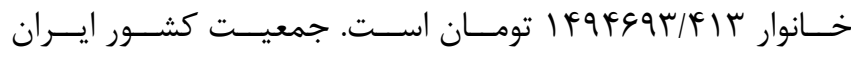
نفو V9T\&YV.

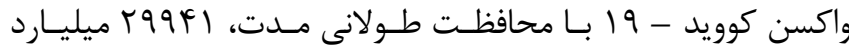
تومان است. متغير وابسته تمايل به يرداخت بــراى سـاليانه واكسـن زدن بر روى متغيرهاى توضيحى در آزمون رگرسيون بررسى گرديد برديد
احتمال يذيرش متغير وابسته نشان مىدهند ولـى تفسـير مقـدارى ندارند، بلكه اثرات نهايى هستند كه مورد تفسير قرار مى گيريرنـد. اثـر

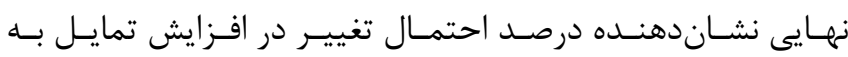
يرداخت، به ازاى تغيير يك واحــــ در متغيـر مسـتقل اسـت كــه در

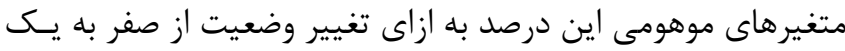

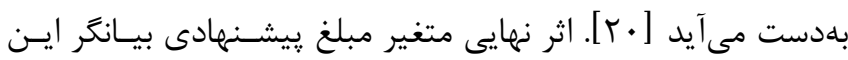
است كه افزايش يك واحدى در قيمت بيشنهادى در صـورت ثابست

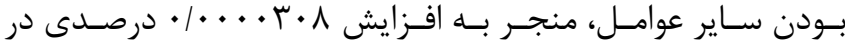

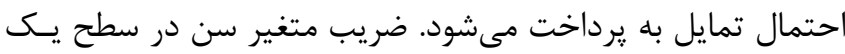

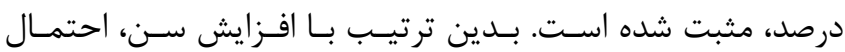
يذيرش مبلغ بيشنهادى افزايش مىيابد. اثر نهايى متغير سن بيـانگر

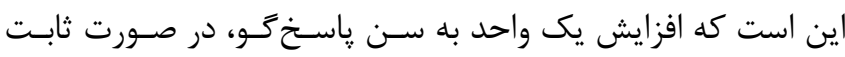

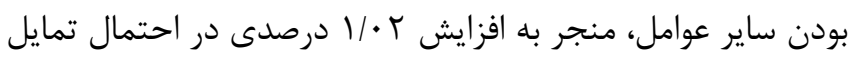
باه برداخت مىشود.

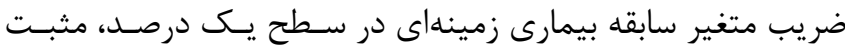
شده است. اين بيانگر اين است كه افرادى كه خــود يـا نزديكانشـان

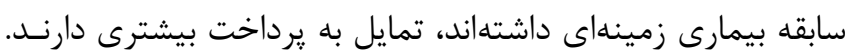
اثر نهايى متغير سابقه بيمارى زمينهاى بيانگر اين است كه افـزايش

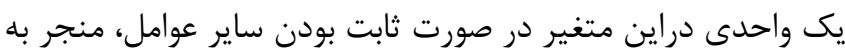

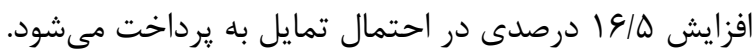

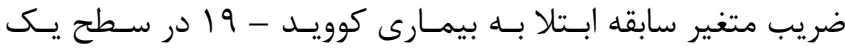
درصد، مثبت شده است. اين بيانكر اين است كه افرادى كه خود يـا

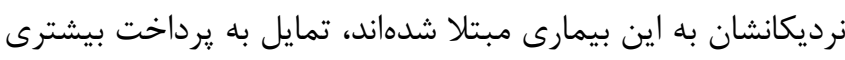

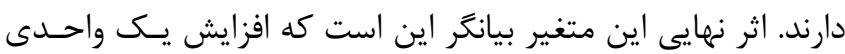
در متغير سابقه بيمارى، در صورت ثابت بودن ساير عوامل، منجر به به يه

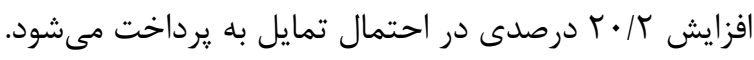

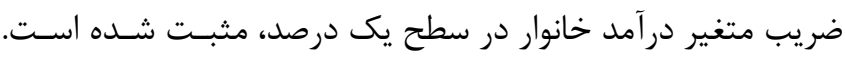

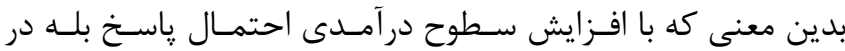
تمايل به يرداخت افزايش مى يابد. اثـر نهـايى متغيـر در آمــد خـانوار

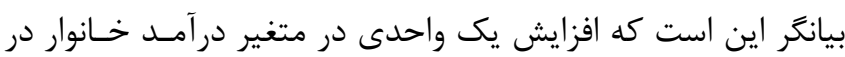

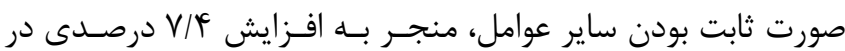
احتمال تمايل به پرداخت مى صورد. ضريب متغير نكرش افراد در سطح يك درصد، مثبت شده است. كه به علامت مورد نظر مطابق با نظريه است. اثر نهـايى ايسن متغيربيـانغر

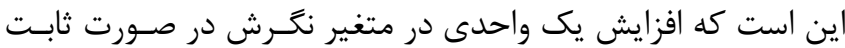
بودن ساير عوامل، منجر به افزايش V/9 درصدى در احتمـال تمايـل 


$$
\text { ساناز رحيمى كاه كشى و همكاران }
$$

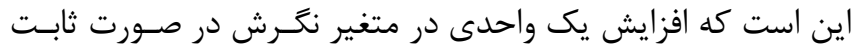

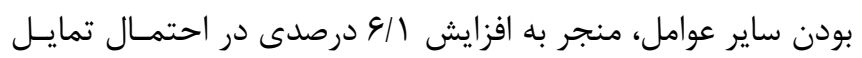

$$
\text { به برداخت مىشود. }
$$

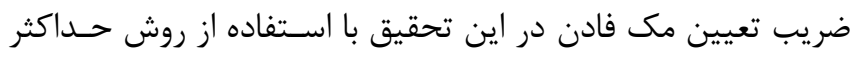

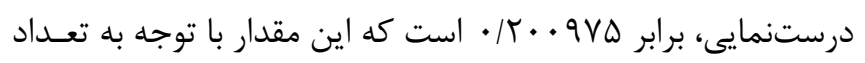

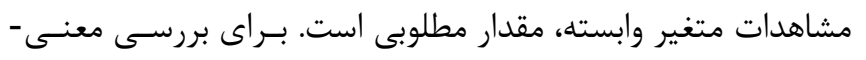

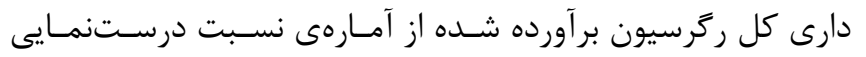

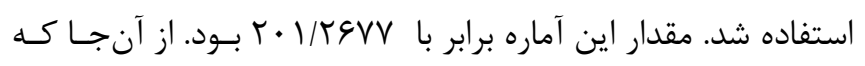

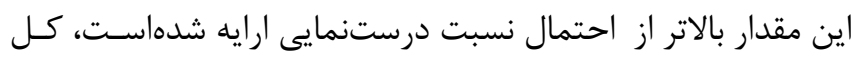

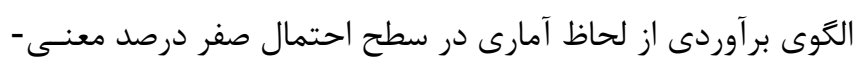

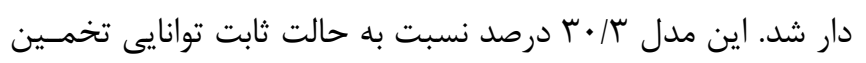

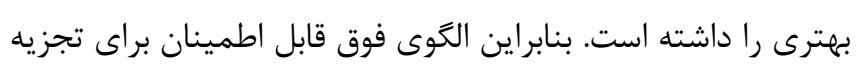
و تحليل هاى بعدى است.

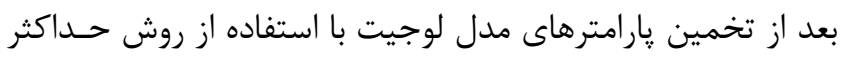

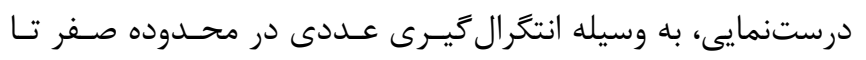

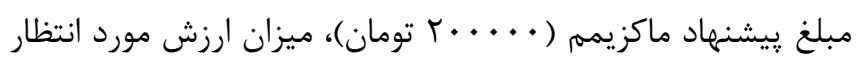

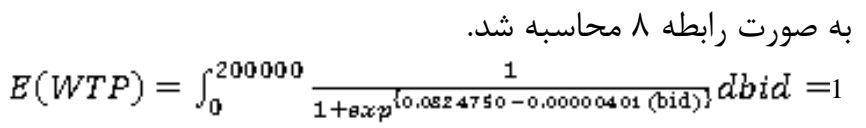
رابطه(9)

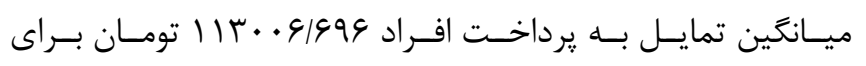

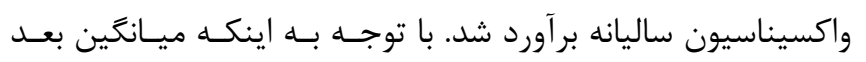

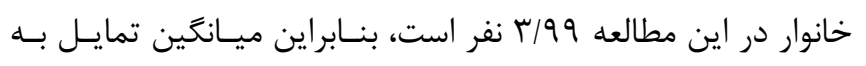

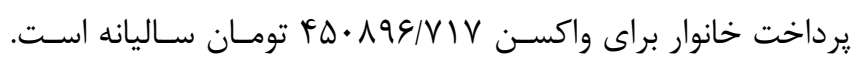

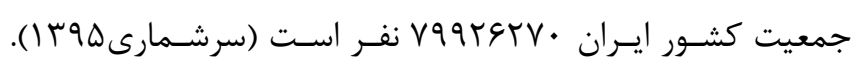

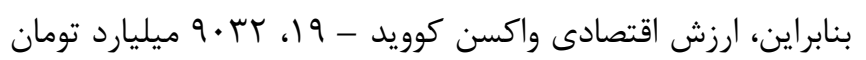

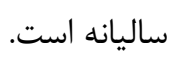

و ضرايب برآورد شده پـس از حـذف متغيرهـاى بـى معنسى مطـابق

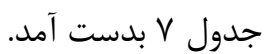

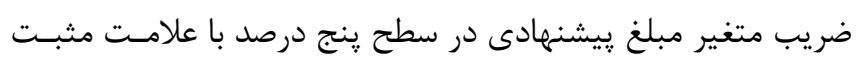

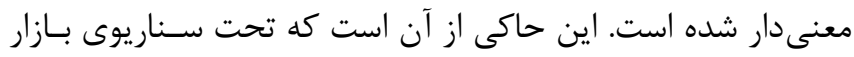

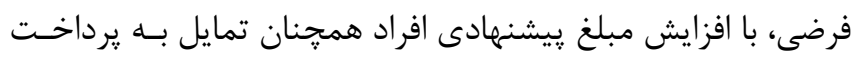

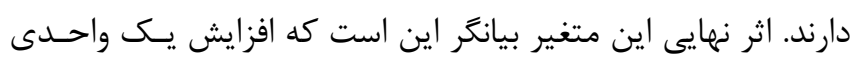

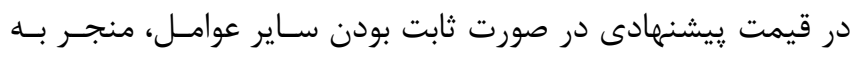

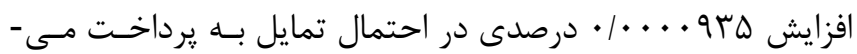
شود. - مبر

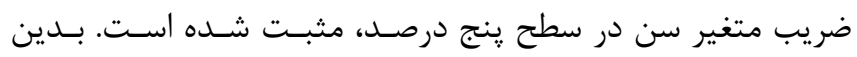

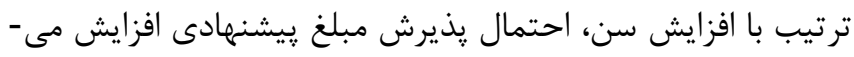

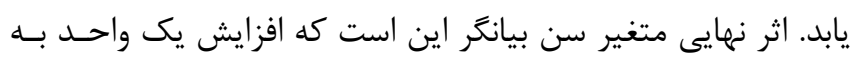

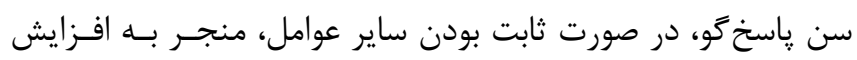

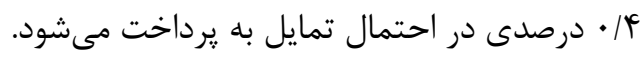

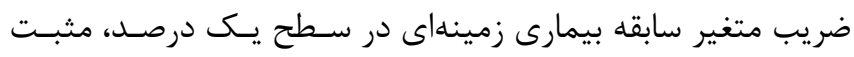

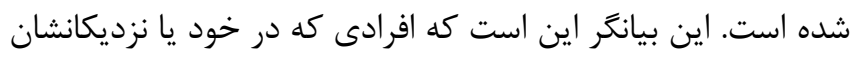

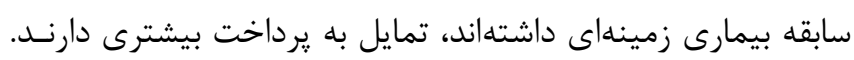

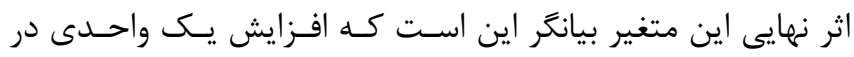

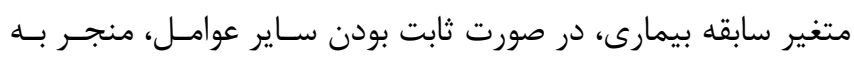

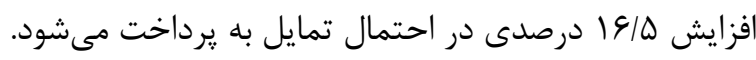

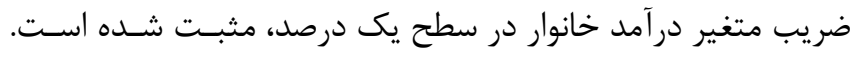

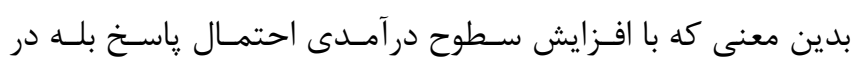

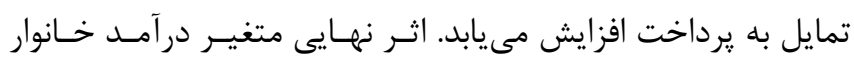

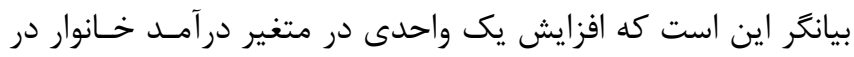

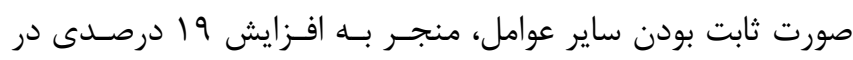

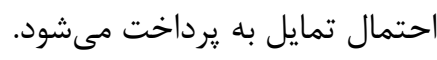

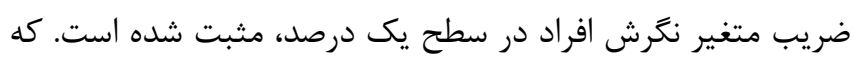
علامت مورد نظر مطابق با نظريه است. اثر نهايى متغير نكرش بيانكر 
سال بيستم، شماره دوم، فروردين ـارديبهشت . If

نشريه يزوهشكده علوم بهداشتى جهاددانشكاهى

\begin{tabular}{|c|c|c|c|c|}
\hline \multirow{3}{*}{ ضريب تغييرات } & \multirow{3}{*}{$\begin{array}{l}\text { حداكثر } \\
v \cdot\end{array}$} & & \multicolumn{2}{|c|}{ جدول ا: نتايج توصيفى متغيرهاى كمى } \\
\hline & & 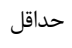 & ميانكَين & \\
\hline & & 11 & $r \Delta / 9$ & سن (سال) \\
\hline$\cdot / 4$ & rr & r & $\mid r / r$ & سالهاى تحصيل (سال) \\
\hline$\cdot \pi \Delta$ & 1. & 1 & $r / 9$ & بعد خانوار (نفر) \\
\hline $1 / \cdot 9$ & $1 \ldots \ldots$ & . & IrAVด৭A/V & در آمد ماهيانه فرد (تومان) \\
\hline . 19 & $r \Delta \ldots .$. & . & rqTr|fi/q & درآمد ماهيانه خانوار (تومان) \\
\hline
\end{tabular}

جدول ז: وضعيت افراد در مقابل خطر كرونا ويروس

\begin{tabular}{|c|c|c|c|}
\hline 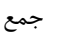 & 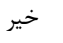 & 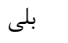 & \\
\hline 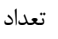 & 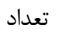 & 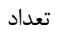 & \\
\hline درصد & درصد & 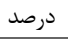 & \\
\hline $1 \cdots$ & FN/V & $\Delta 1 / \pi$ & \\
\hline rv. & $|V|$ & 199 & سابقه بيمارى زمينهاى \\
\hline rv. & $r \mid \Lambda$ & IDT & وجود فرد مسن در خانواده \\
\hline $1 \cdots$ & $\Delta 9$ & $r \cdot 1 /$ & \\
\hline rv. & rAs & $\Lambda F$ & فوت نزديكان بدليل بيمارى كوويد \\
\hline $1 \ldots$ & $V V / r$ & $T r / V$ & \\
\hline
\end{tabular}

جدول r: دسته بندى افراد بر اساس نكرش افراد به واكسن كوويد 19

\begin{tabular}{|c|c|c|c|c|c|}
\hline جمع & مثبت & نسبتاً مثبت & نسبتاً منفى & منفى & \\
\hline$r v \cdot$ & Ve & 110 & $|r|$ & $i \wedge$ & تعداد \\
\hline $1 \cdots$ & $r \cdot / \Delta$ & $m / l$ & $r \Delta /{ }^{\epsilon}$ & ir & درصد \\
\hline
\end{tabular}

جدول F: توزيع فراوانى تمايل به يرداخت افراد نمونه مورد بررسى ( واكسناسيون طولانى مدت)

\begin{tabular}{|c|c|c|c|}
\hline 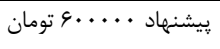 & رِيشنهاد .... لهاتومان & קيشنهاد ....."اتومان & \\
\hline (ييشنهاد بالاتر) & (ييشنهاد پايينتر) & (ييشنهاد ميانى) & \\
\hline IT & rI & TIT & بلى \\
\hline אז/זr & $\Lambda / r \Lambda$ & $\Delta V / T q$ & درصد \\
\hline 19 & ITV & $1 \Delta \Lambda$ & خير \\
\hline$r F / .9$ & MY/MT & FT/V & درصد \\
\hline TIT & $\mid \Delta \Lambda$ & rv. & مجموع \\
\hline$\Delta V / T q$ & $F T / V$ & $1 \cdots$ & درصد \\
\hline
\end{tabular}

جدول ه:توزيع فراوانى تمايل به يرداخت افراد نمونه مورد بررسى ( واكسيناسيون ساليانه)

\begin{tabular}{|c|c|c|c|}
\hline 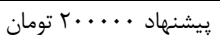 & 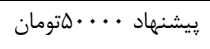 & ״يشنهاد .... & وضعيت پذيرش \\
\hline (پيشنهاد بالاتر) & (پيشنهاد پايينتر) & (يشنهاد ميانى) & \\
\hline אזו & re & $r \cdot q$ & بلى \\
\hline$r \Delta / q \uparrow$ & $9 / 19$ & $\Delta G / F \wedge$ & درصد \\
\hline ve & IrV & 191 & خير \\
\hline$T \cdot / D F$ & TH/Tr & $f r / \Delta)$ & درصد \\
\hline$r \cdot q$ & 191 & rve & مجموع \\
\hline$\Delta G / F \wedge$ & $F r / D \mid$ & $1 \cdots$ & درصد \\
\hline
\end{tabular}


IF.. سال بيستم، شماره دوم، فروردين - ارديبهشت

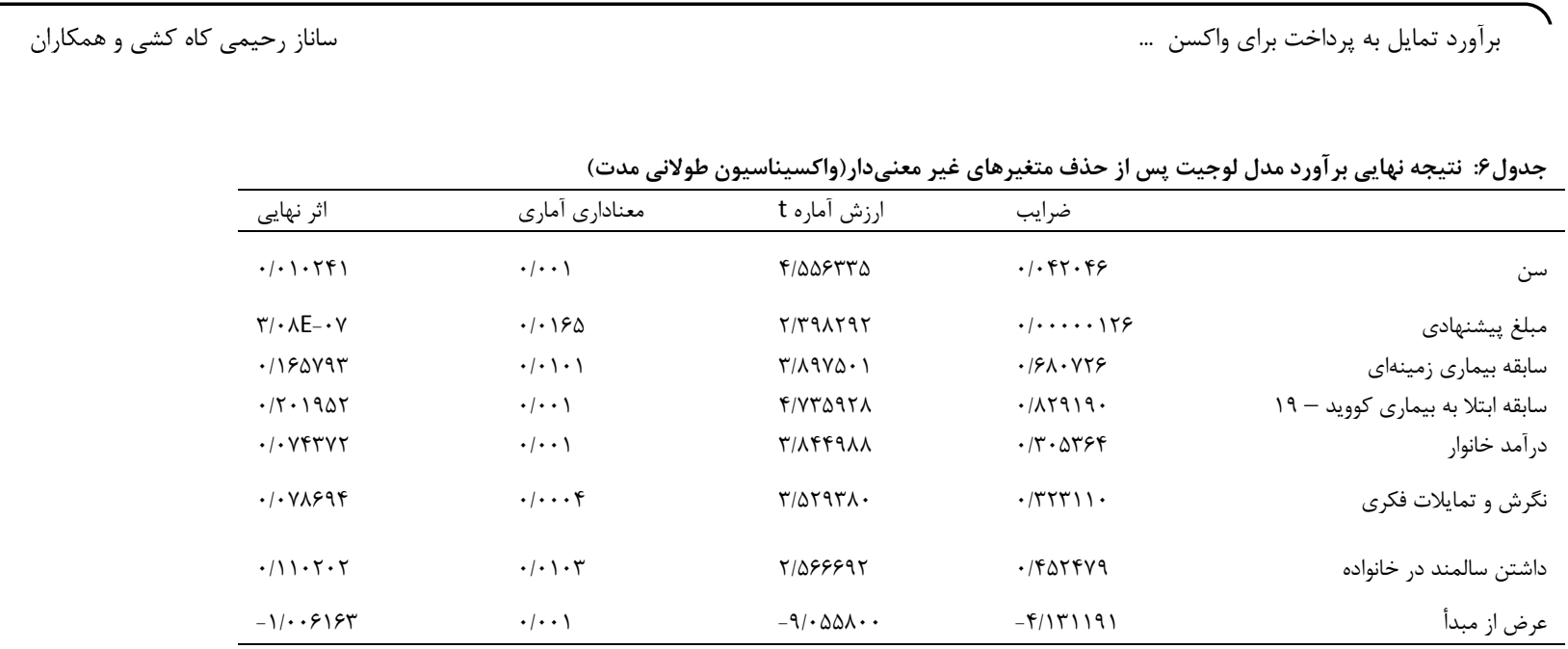

\begin{tabular}{|c|c|c|c|c|}
\hline اثر نهايى & معنادارى آمارى & إرزش آماره t & از حذف متغير & جدول V: نتيجه نهايى : \\
\hline$\cdot|\cdot \mu r \cdot|$ & . & $r / .11 \mathrm{fVr}$ & . / IAfrq & - ان \\
\hline$q / \Gamma \Delta \mathrm{E}-\cdot \vee \vee$ & .1 .149 & T/FADTHA & $\cdot \mid \cdots+\cdot+\cdot 1$ & مبلغ بيشنهادى \\
\hline - /19DVQT & $.1 . .1$ & $4 / .99491$ & ./VI911r & سابقه بيمارى زمينهاى \\
\hline$\cdot / / \Lambda \Lambda \wedge \& \Delta$ & $.1 . .1$ & $9 / 1.944 \pi$ & - $11 \cdot 9419$ & 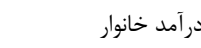 \\
\hline $.1 .9 \cdot 91 \mathrm{~F}$ &..$+F \Delta$ & r/ArqVYA. & . RGITTV & تكرش و تمايلات فكرى \\
\hline$-\cdot / 1 \cdot q q V V$ & $.1 . .1$ & -V/ArqrqA & $-r / \& \& \wedge V Y q$ & عرض از مبدأ \\
\hline
\end{tabular}

كرملاجعب اين متغير تأثير معنى دارى از نظر آمـارى نـدارد امـا در

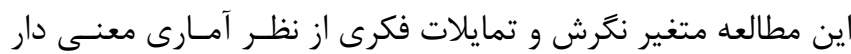

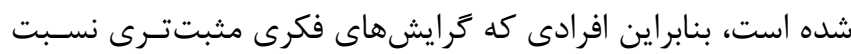

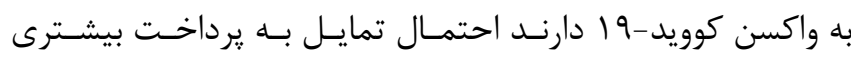

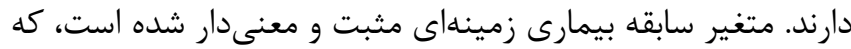

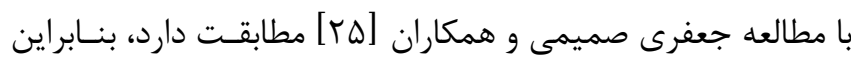

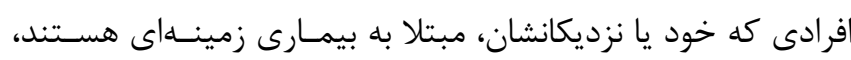
احتمال بيشترى براى تمايل به يرداخت دارند. متغير سـابقهى ابـتلا

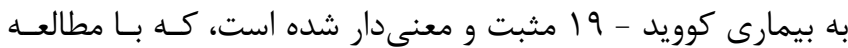

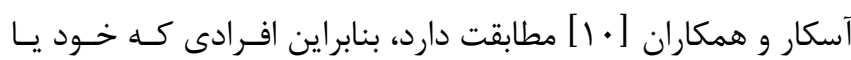

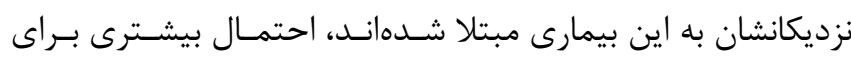

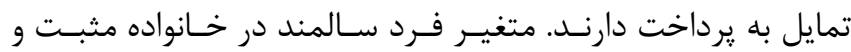

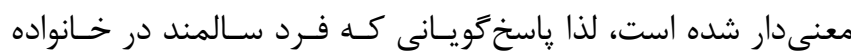

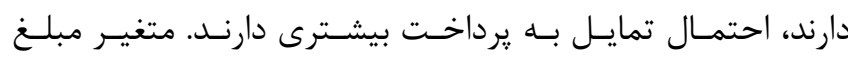

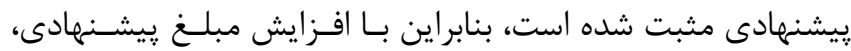

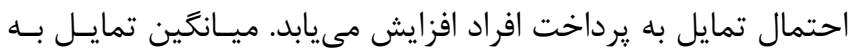

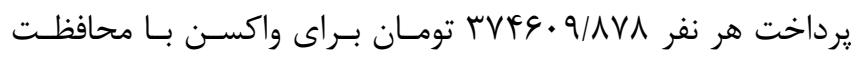

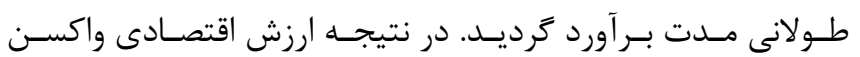

\section{بحث و نتيجه گيرى}

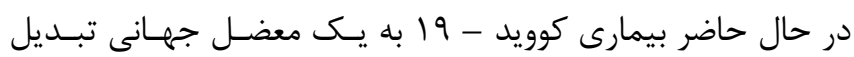

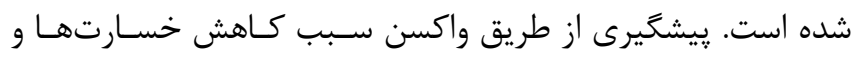

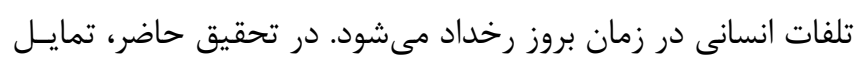

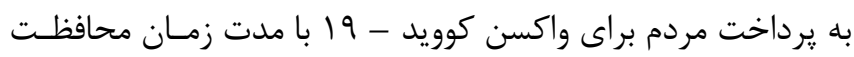

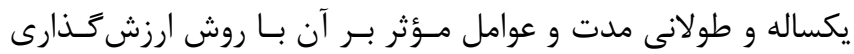

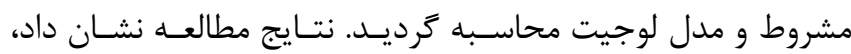

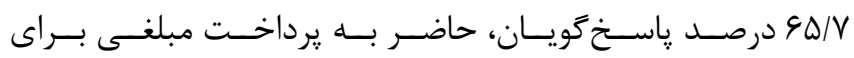

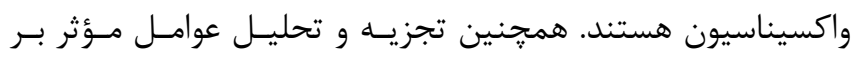
تمايل به يرداخت افراد براى واكسن با محافظت طولانى مدت نشـان

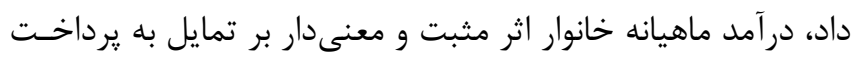

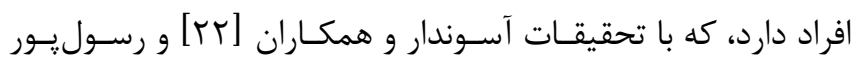

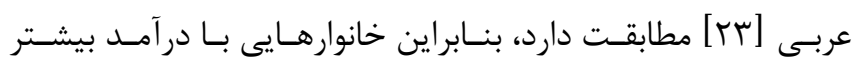

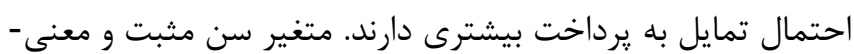

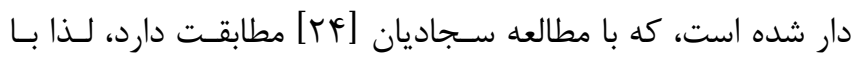

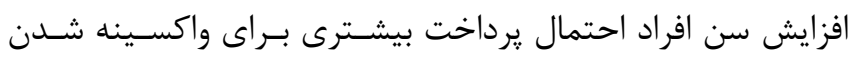

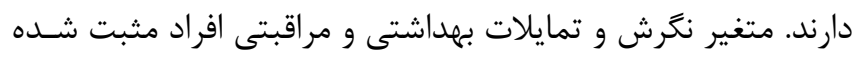

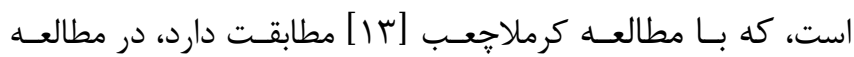


با توجه به نتايج بدست آمده يِيشنهادهايى در راسـتاى هـر جـــه

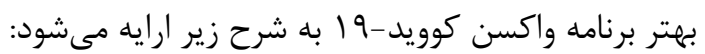

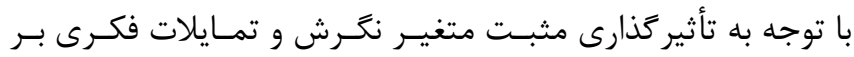

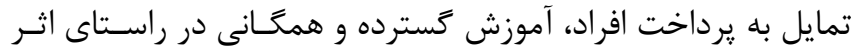
بخشى واكسن در ييشخيرى از كوويد - 19 در دستور كار قرار گيرد.

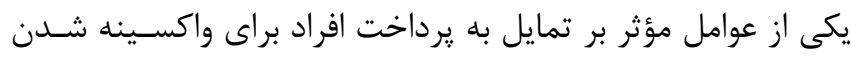

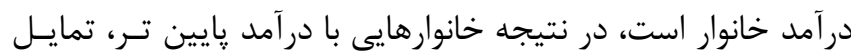

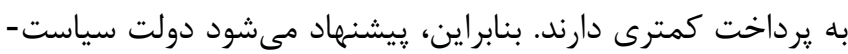

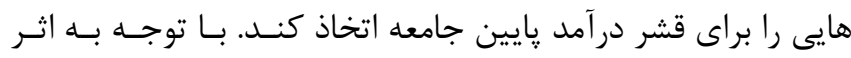

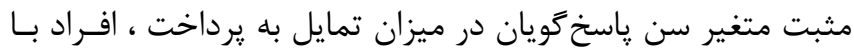
سنين يايينتر تمايل به يرداخت كمترى نسبت به افراد با سنين بالا بهري

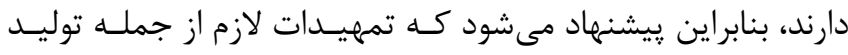

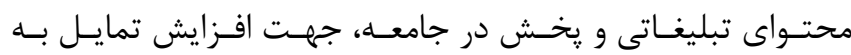

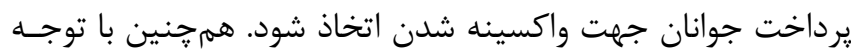

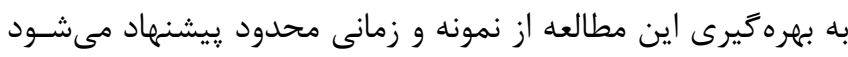

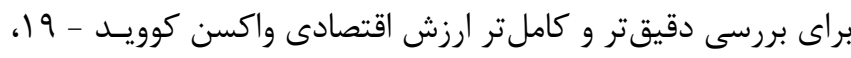

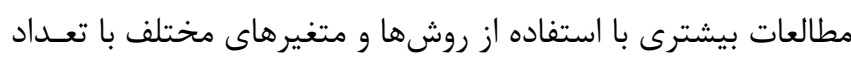

$$
\text { مشاهدات بيشتر برآورد شود. }
$$

تضاد منافع: نويسندكان اظهار داشتند كه تضاد منافعى وجود ندارد.

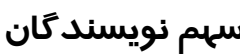

اميدعلى عادلى: استاد راهنما، نوشتن مقاله ساناز رحيمى: طراحى و اجراى مطالعه، نوشتن مقاله

\section{تشكر و قدردانى} از كليه شركت كنندFان يزوهش تشكر و قدردانى مىشود.

\section{منابع}

1. Pendar M, Javaheri A, Vafaei E. Environmental effects of Covid - 19. Paper presented at the National Conference on Green Studies, Computation, Applications and Challenges in Mazandaran, Noor City. Retrieved on the website http://civilica.com/doc/1116719 . 2020.[In Persian]

2. Abdi K, Vafaei F, Weiss S. Survey of thoughts and anxiety of corona heart disease in Kermanshah. Paper presented at the Second Newly Founded Congress in the Field of Family, Mental Health, Disorders, Prevention and Education in Tehran, retrieved on the website http://civilica.com/doc/1038143. 2020.[In Persian]

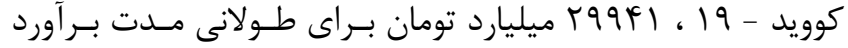

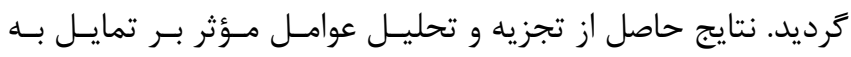

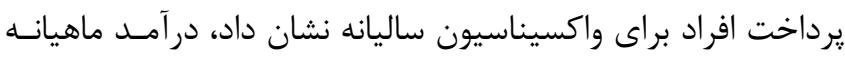

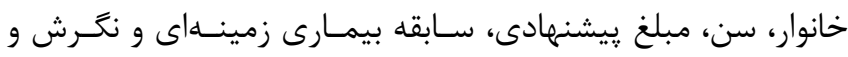
تمايلات فكرى ياسخ گو درباره واكسن اثر مثبت و معنى دار بر تمايل

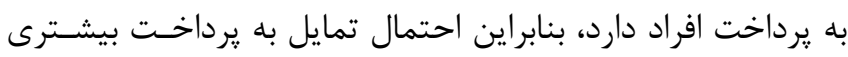

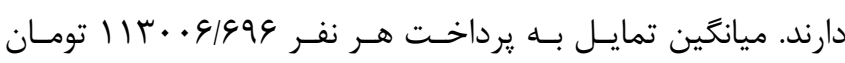

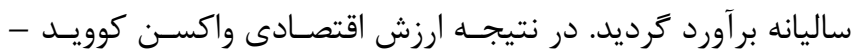

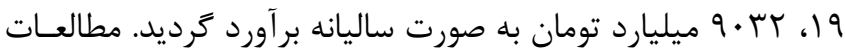
قبلى در مورد واكسنهاى فرضى طيف گستردهاى از مقـادير تمايـل به يرداخت را زَزارش كردهاند كه احتمالاً ناشى از تفاوت در ويزگ هاى بيمارى و جمعيت مورد مطالعه است.به عنوان مثال، تمايل بـهـ

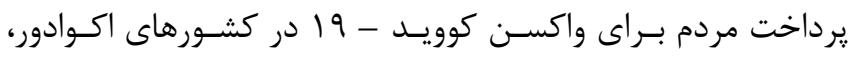

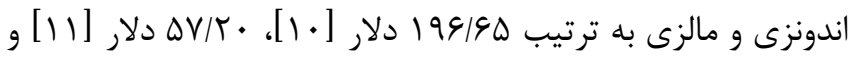

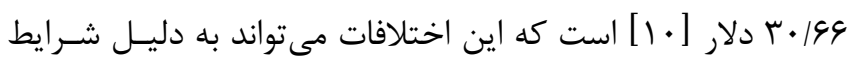
فرهنكى، بهداشتى واقتصادى در هر كشور و همجنين وضـعيت ايسن

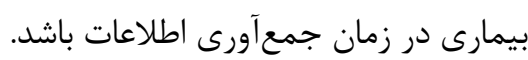

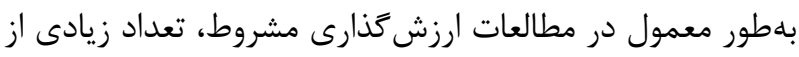

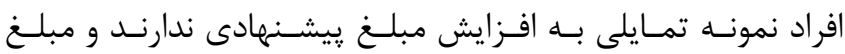
ييشنهادى كمتر را براى سياست مورد مطالعه بيشنههاد مى كنند. اما

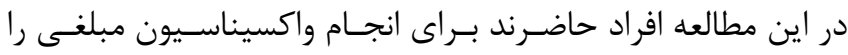
يرداخت كنند، اين نشان مى دهد كه مردم به خوبى اهميت و خطـر

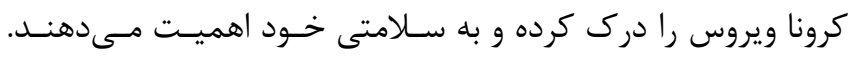
بنابراين، به نظر مىرسد كه اين برنامه، از ديدكاه مردم حائز اهميـت

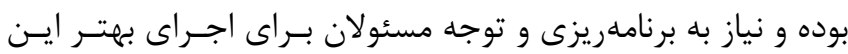
برنامه دارد.

3. Roshan Khah, Gh. Areview article on the psychological and social consequences of corona virus in Iranian society. Paper presented at the First National Conference on Applied Research in the Education Process in Hormozgan, Minab, retrieved from the website http://civilica.com/doc/1116457 . 2020. [In Persian]

4. Beit Siyahi M. Investigating the effects of corona heart disease and several global epidemics on several economic variables. Paper presented at the Second International Conference on Innovative Technologies in Science, Engineering and Technology in Munich, 
سال بيسته، شماره دوم، فروردين - ارديبهشت ..|F

Germany, retrieved from the website http://civilica.com/doc/1022231 . 2020. [In Persian] 5. Saebniya S, Karimi, F. The effect of corona heart disease (Covid - 19) on personal and work performance (Case study of small and medium businesses in Ardabill province). Journal of Accounting and Management Perspective 2020; 4:83 93 [In Persian]

6. Mokhber Alsafa L, Forqani S, Hagheghe S, Afkhamnia M. Satisfaction and attitude of farmers in industrial farms regarding Brucellosis Sharbon and Tab barfaki produced by Razi Institute (2014 - 2015). Journal of Veterinary Research and Biological Products (Research and Construction) 2017; 2: 119 127.Doi: 10.22034/vj.2017.109229. [In Persian]

7. Nick $H$, Shogren Jason $F$ and Ben W. Environmental Economics in Theory and Practice. $2^{\text {th }}$ Edition, Basingstoke : Palgrave Macmillan; 2007

8. Yulan L, Zheng L, Fei H, Huilin Ch, Xi L, Gregory $\mathrm{D}$, et al. HPV vaccination intent and willingness to pay for $2-4$, and 9 - valent HPV vaccines: A study of adult women aged $27-45$ years in China. Journal of Vaccine 2020; 38: 3021 - 3030. Doi: 10.1016/j.vaccine.2020.2.042.

9. Harapan H, Samsul A, Aslam B, Arsil R, Pradiba A, Riny $\mathrm{F}$, et al. Willingness to pay for a dengue vaccine and its associated determinants in Indonesia: A community - based, cross - sectional survey in Aceh. Journal of Acta Tropica 2017; 166: 249 - 256. Doi: 10.1016/j.actatropica.2016.11.035.

10.Oscar S, Carlos E, Darren H, Patricia A, Guerrero $\mathrm{O}$, Ivan $\mathrm{B}$. The demand for a COVID - 19 vaccine in Ecuador. Journal of Vaccine 2020; 38:8098 - 8090. Doi: $10.1016 / \mathrm{j} / \mathrm{vac}$ ane.2020.11.013.

11. Harapan $\mathrm{H}$, Wagner $\mathrm{AL}$, Yufika $A$, Winardi $W$, Anwar S, Gan AK, et al. Acceptance of a COVID - 19 vaccine in Southeast Asia: A cross - sectional study in Indonesia. Journal of Front Public Health 2020;8:31 doi: 10.3389/fpubh.2020.00381

12. Ghaderi H, Wawankhah S, Khoshkam M, Rouhani B. Estimation of willingness to pay for breast cancer screening with mammography in women living in Tehran using conditional valuation method (cvm) in 2010. Journal of Health Management 2012; 15: 33 46 [In Persian]

13. Karamlachab A. Valuation of air quality improvement in Ahvaz city (Case study: Dust phenomenon). Master Thesis in Environmental Economics Engineering, Tabriz University of Agriculture. 2014. [In Persian]
14. Adeli O, Ansari Samani H, Fereydoni N, Zare Qaleh Sidi R. Estimation of reational value of Bamoo National Park in Fars province using conditional valuation method. Journal of Enviromental Science Studies 2017; 2: 87 - 100 [In Persian]

15. Hatami M. Estimating the recreational value of Yazd Mountaing Park. Master Thesis in Agricultural Engineering, majoring in Agricultural Economics, payame Noor University, Karaj Branch. 2012 [In Persian]

16. Hedayati M, Incorrect substitution of standard deviation and standard deviation from the average in biomedical science articles. Journal of Exercise physiology 2009; 1: 65 - 69 [In Persian]

17. Souri A. Advanced econometrics, First Edition, Cultural Studies Publications. Tehran 2012, Volume 2. [In Persian]

18. Tavakoli Rad Gh. Estimation of economic recreational value of a complete forest park using conditional valuation method. Master Thesis in Economics majoring in Enviromental Economics, University of Economic Allameh Tabatabai. 2017 [In Persian]

19. Amirnejad H. Ajdari S. Comparison of the use of logit, probit and tobit in the economic valuation of environmental resources: Case study estimating the rotational value of the lost paradise area of Fars province. Journal of Agricultural Economic 2011; 5: 95 - 119 [In Persian]

20. Kikha E. Investigating the willingness to pay insurance premiums by wheat farmers in Golestan province and the factors affecting it. Master Thesis in Agricultural Economics, University of Zabol. 2018 [In Persian]

21. Khadem Baladipour T. Estimating the recreational value and determining the factors affecting the willingness of visitors to pay in Ghori Gol wetland. Master Thesis in Agricultural Management. University of Tabriz. 2009 [In Persian]

22. Osundare F O, Oluwatusin F M, Toluwase S O W, Adekunmi A O, Ajiboye A. Arifalo S F. An Evaluation of Accessibility and Willingness to Pay for Water by Rural Households in Ondo State, Nigeria. Journal of Agriculture and veterinary Science 2020; 13: $34-41$

23. Rasoolpour Arabi M. Recreational valuation of Babolsar city beaches using conditional valuation method. Master Thesis in Economics, majoring in Environment, University Allameh Tabatabai.2017 [In Persian] 
24. Sajjadian, M., Neshat, A., Fattahi Ardakani, A. Economic study of the possibility of improving air quality in the metropolis of Arak. Journal of Agricultural Economics Research 2020; 12: 19 - 34 [In Persian]
25. Jafari Samimi A, Karimi S, Mohammadi T, Tatar M. Estimation of willingness to pay for supplementary insurance using conditional valuation method $(\mathrm{CV})$ and logit regression model. Journal of Investigating Irans economic issues 2019; 6: 81 - 107 [In Persian] 


$$
\text { טيوست : يرسشنامه تمايل به يرداخت مردم براى واكسن كوويد - } 19
$$

$$
\text { بسمه تعالى }
$$

با سلام و احترام

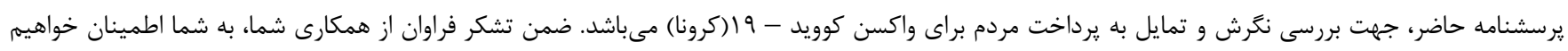

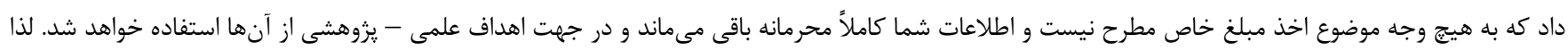

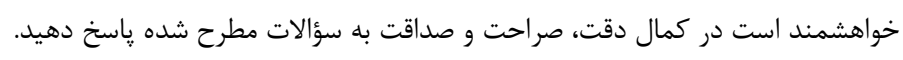

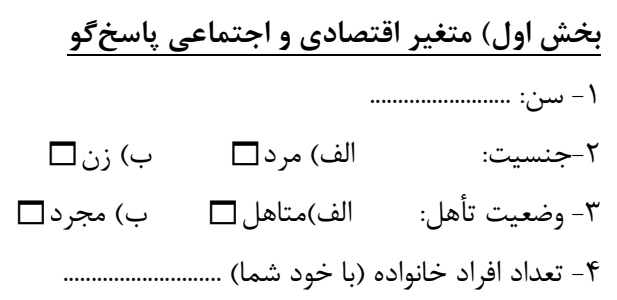

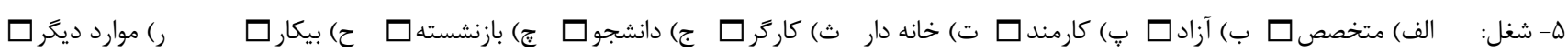
ج)زير دييله)

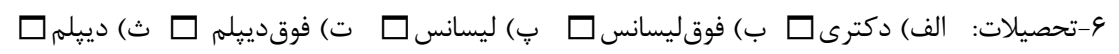
ح ) بيسواده

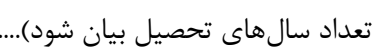

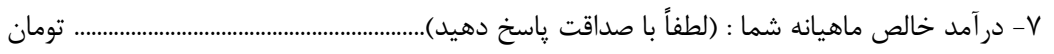
. تومان

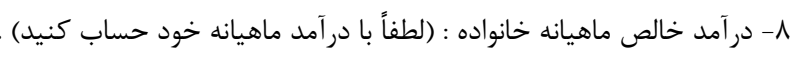

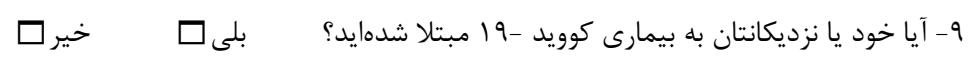

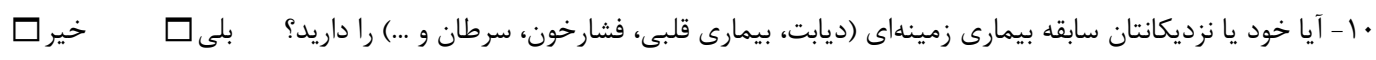

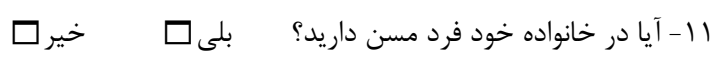

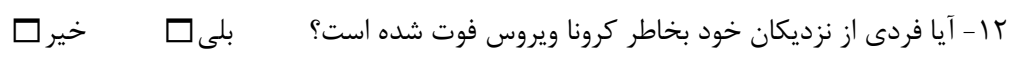
بخش دوم) متغير دانش و آتاهى باسخَّو

\begin{tabular}{|c|c|c|c|c|c|}
\hline آكاهى خيلى زياد & آنآهى زياد & 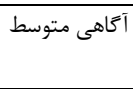 & 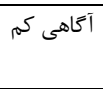 & آكَاهى خيلى & سنجش متغير دانش و آكاهى ياسخ كَو نسبت به بيمارى كويد - 19 \\
\hline & & & & & ماسك زدن و رعايت فاصله اجتماعى مانع از انتقال كرونا ويروس مىشود. \\
\hline & & & & & يول يقد و دست دادن يكى از راههاى انتقال كرونا ويروس است. \\
\hline & & & & & ضدعفونى و شستوشوى وسايل خريدارى شده مانع از انتقال كرونا ويروس مىشود. \\
\hline & & & & & يوشاندن دهان و بينى حين عطسه و سرفه مانع از انتقال كرونا ويروس مىشود. \\
\hline & & & & & جلوكيرى از تجمع و ازدحام مى توانداز ابتلا به ويروس كرونا جلوكيرى نمايد \\
\hline
\end{tabular}
با ا - ميزان آكاهى خود را نسبت به هريك از سوالات با توجه به طيف بيان كنيد. 
سال بيستم، شماره دوم، فروردين - ارديبهشت .. س

نشريه يزوهشكده علوم بهداشتى جهاددانشكاهى

\section{بخش سوم) تمايلات و كرايشهاى بهداشتى و مراقبتى ياسخگو}

f أ- تمايلات خود را نسبت به هر يك از سوالات با توجه به طيف بيان كنيد.

\begin{tabular}{|c|c|c|c|c|c|}
\hline كاملاً موافقم & موافقه & 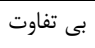 & مخالفم & كاملاً مخالفم & سنجش نكَرش يا تمايلات فكرى باسخَّو به واكسن كوويد - 19 \\
\hline & & & & & واكسن كوويد - 19 ، شانس بيمار شدن را كاهش مىدهد. \\
\hline & & & & & واكسن كوويد - 19 كه به مرحله توليد رسيده است، ايمنى و اثر بخشى بالايى دارد. \\
\hline & & & & & هزينه واكسن كوويد - 9 1، بهصرفهتر از هزينه درمان بيمارى است. \\
\hline & & & & & واكسن كوويد - 19، در بيشَّيرى از بيمارى مؤثر نخواهد بود. \\
\hline & & & & & واكسن كوويد - 9 ، عوارض جانبى دارد. \\
\hline
\end{tabular}

fl |- ميزان تمايل شما براى انجام واكسن كوويد - 19 جقدر است؟

\begin{tabular}{|c|c|c|c|}
\hline 0) خيلى كم & د) كمى & ج) متوسط & ب) زياد \\
\hline
\end{tabular}

\section{بخش جهارم) ارزشخذارى مشروط}

هموطن كرامى

فرض كنيد واكسن توليد شده براى بيمارى كوويد - 19، ايمنى و اثر بخشى بالايى دارد.

1- جنانجه اين واكسن بهصورت رايخان ارائه نشود، آيا حاضريد مبلغى را براى دريافت واكسن بِردازيد؟ بلى $\square$ (به سوال r برويد) خير $\square$ ( به سوال أ برويد)

تومان ץ- حداكثر مبلغى كه حاضريد براى بهرهمندى از اين واكسن بِردازيد جقدر است؟ ( جنانجه يك بار زدن واكسن كفايت نمايد)

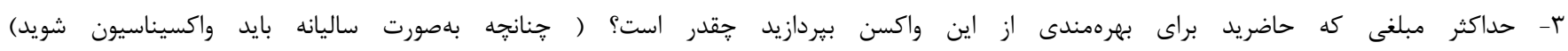
تومان..........

ץ - اكر جوابتان در مورد سوال ا "خير" است، جرا تمايل به يرداخت جهت دريافت واكسن نداريد؟( فقط يك كزينه را انتخاب كنيد)

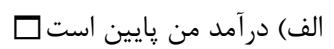

ب) نداشتن اطمينان از اثربخشى واكسن كوويد -

ج) دولت بايد بيردازد $\square$

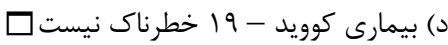

ه- جنانجه نظر يا پيشنهاد خاصى مد نظر شما است، ذكر فرماييد.

اينجانب و دانشعاه قم از شما به خاطر وقت و همكاريتان تشكر مى كنيم. 